\title{
SPESIASI DAN BIOAVAILABILITAS LOGAM BERAT CU DAN Zn DALAM TANAH PERTANIAN ORGANIK DAN ANORGANIK
}

\author{
N. W. B. S. Devi", I M. Siaka, dan K. G. D. Putra \\ Program Studi Kimia, Fakultas Matematika dan Ilmu Pengetahuan Alam, Universitas Udayana \\ Jalan Kampus Unud-Jimbaran, Jimbaran-Bali, Indonesia \\ *e-mail: bintangsridevi@gmail.com
}

\begin{abstract}
ABSTRAK
Pertanian di Indonesia secara umum cenderung memanfaatkan agrokimia untuk meningkatkan kualitas dan kuantitas hasil pertanian, namun tanah maupun produknya dapat tercemar khususnya oleh logam berat. Penelitian ini bertujuan untuk menentukan logam total, spesiasi, dan bioavailabilitas $\mathrm{Cu}$ dan $\mathrm{Zn}$ dalam tanah pertanian organik dan anorganik di Kecamatan Blahbatuh Kabupaten Gianyar. Metode ekstraksi bertahap digunakan untuk melepaskan ikatan logam berat tersebut dalam setiap komponen tanah dan penentuan konsentrasi logamnya dilakukan dengan menggunakan AAS. Berdasarkan kandungan logam total $\mathrm{Cu}$ dan $\mathrm{Zn}$ baik tanah organik maupun anorganik tersebut masih tergolong sebagai tanah yang belum tercemar karena kandungannya berada jauh di bawah ambang batas maksimum yang diperbolehkan yaitu 45,3922 mg/kg Cu dan $47,7645 \mathrm{mg} / \mathrm{kg} \mathrm{Zn}$ pada tanah organik dan 48,9121 mg/kg Cu dan 49,9474 mg/kg Zn pada tanah anorganik. Tanah organik dan anorganik dengan fraksi EFLE (easly, freely,leachable, and exchangeable), reducible, oxidisable, dan resistant yang berasosiasi dengan logam berturut-turut yaitu $\mathrm{F} 4>\mathrm{F} 3>\mathrm{F} 2>\mathrm{F} 1$ untuk $\mathrm{Cu}$ dan $\mathrm{F} 4>\mathrm{F} 3>\mathrm{F} 1>\mathrm{F} 2$ untuk $\mathrm{Zn}$. Bioavailabilitas $\mathrm{Cu}$ dan $\mathrm{Zn}$ dalam tanah organik berturut tutut: 10.52-23,79\% dan 3,797,21\% bioavailable, $10.03-25.50 \%$ dan $14.99-32.68 \%$ berpotensi bioavailable, 38,64-63,19\% dan 41.20-60.28\% non bioavailabel. Sementara pada tanah anorganik:18,31-32.63\% dan 4.54-7,85\% bioavailable, 9,86-13,85\% dan 15,26-32.55\% berpotensi bioavailable, 40,20-59,14\% dan 42,84-58,26\% non bioavailable. Dengan demikian, kedua jenis tanah pertanian tersebut tidak berbahaya jika digunakan untuk menanam berbagai jenis padi.
\end{abstract}

Kata Kunci : bioavaibilitas, $\mathrm{Cu}$ dan $\mathrm{Zn}$, spesiasi, tanah pertanian

\begin{abstract}
Agriculture in Indonesia generaly applies agrochemical to improve the quality and quantity of the products, but the impact is, both lands and their products could be contaminated by pollutans especially heavy metals. This study aimed to determine the total metals, speciation, and bioavailability of $\mathrm{Cu}$ and $\mathrm{Zn}$ in organic and inorganic agricultural soils in Blahbatuh District, Gianyar Regency. The sequential extraction method was performed to release the bonds of heavy metals in each soil component and the determination of the metal concentration was carried out using AAS. The total metals of $\mathrm{Cu}$ and $\mathrm{Zn}$ in both organic and inorganic soils indicated that both type of soils were still classified as uncontaminated soils because the metal contents were below the maximum limit allowed. The total contents of $\mathrm{Cu}$ and $\mathrm{Zn}$ in the organic soil were of $45.3922 \mathrm{mg} / \mathrm{kg}$ and $47.7645 \mathrm{mg} / \mathrm{kg}$, respectively, while $\mathrm{Cu}$ and $\mathrm{Zn}$ in the inorganic soil were $48.9121 \mathrm{mg} / \mathrm{kg}$ and $49.9474 \mathrm{mg} / \mathrm{kg}$, respectively. Fractination in the organic and inorganic soil EFLE (easly, freely,leachable, and exchangeable), reducible, oxidisable, dan resistant including F4> F3> F2> F1 for $\mathrm{Cu}$ and F4> F3> F1> F2 for Zn. The bioavailability of $\mathrm{Cu}$ and $\mathrm{Zn}$ in the organic soils were $10.52-23.79 \%$ and $3.79-7.21 \%$ bioavailable, $10.03-25.50 \%$ and 14.99 $32.68 \%$ potentially bioavailable, $38.64-63.19 \%$ and $41.20-60.28 \%$ non bioavailable, while in the inorganic soil and were $18.31-32.63 \%$ and $4.54-7.85 \%$ bioavailable, $9.86-13.85 \%$ and $15.26-32.55 \%$ potentially bioavailable, and $40.20-59.14 \%$ and $42.84-58.26 \%$ non bioavailable. Consuquenthy, both types of the agricultural soils would be safe for planting various types of rice.
\end{abstract}

Keywords: bioavailability, $\mathrm{Cu}$ and $\mathrm{Zn}$, speciation, agricultural soil

\section{PENDAHULUAN}

Pertanian merupakan salah satu mata pencarian penduduk Indonesia yang utama, karena Indonesia memiliki kekayaan alam yang melimpah dan tanah yang subur sehingga sektor pertanian berkembang pesat. Walaupun tanah pertaniannya subur, namun pengolahannya, para petani cenderung mengaplikasikan agrokimia (pupuk anorganik 
dan pestisida sintetis) untuk meningkatkan hasil pertaniannya baik secara kualitatif maupun kuantitatif.

Hampir semua petani di Indonesia mengendalikan hama dengan mengaplikasikan pestisida seperti insektisida organofosfat hingga 59 \% (Departemen RI 2009). Dampak negatif penggunaan Agrokimia dapat menimbulkan pencemaran logam berat, karena agrokimia banyak mengandung logam berat dan logam berat ini akan masuk ke dalam tanah dan terakumulasi sehingga terjadi pencemaran tanah. Cemaran logam berat seperti $\mathrm{Cu}$ dan $\mathrm{Zn}$ dalam tanah dapat mengakibatkan tanaman yang tumbuh pada tanah tersebut dapat terkontaminasi oleh logam berat tersebut, karena bioavailabilitasnya.

Selain pupuk anorganik, pupuk organikpun dapat meningkatkan cemaran logam berat. Pemberian nutrisi melalui aplikasi pupuk organik yang berasal dari kotoran sapi secara berlebihan dengan jangka waktu lama dapat meningkatkan kandungan logam berat $\mathrm{Cu}$ dan $\mathrm{Zn}$ (Widaningrum, dkk, 2007). Alloway dan Ayres (1997) juga menyatakan bahwa kotoran babi dapat mengandung logam berat $\mathrm{Cu}$ dan $\mathrm{Zn}$ yang tinggi berturut-turut berkisar 300-2000 mg/kg dan 200-1500 mg/kg. Residu pestisida dalam tanah juga banyak mengandung logam berat ( Widowati, 2008) seperti $\mathrm{As}, \mathrm{Cu}, \mathrm{Co}, \mathrm{Cr}, \mathrm{Cd}, \mathrm{Fe}, \mathrm{Hg}, \mathrm{Mn}, \mathrm{Ni}, \mathrm{Pb}$, dan $\mathrm{Zn}$ dan jika logam berat tersebut mengkontaminasi buah dan sayuran, maka sangat berbahaya jika dikonsumsi (Priyoni, 2006).

\section{MATERI DAN METODE}

\section{Bahan}

Tanah organik, anorganik, akuades, asam nitrat, asam asetat, asam klorida, hidroksilamin klorid, hidrogen peroksida, logam $\mathrm{Cu}, \mathrm{Zn}$. Semua bahan yang digunakan memiliki derajat proanalisis.

\section{Peralatan}

Sendok plastik, plastik polietilen, oven, mortar, ayakan ukuran $63 \mu \mathrm{m}$, neraca analitik, penggojog (shaker), sentrifuge, $\mathrm{pH}$ meter, ultrasonic bath, dan seperangkat alat gelas, dan instrumentasi Spektrofotometer Serapan Atom (AAS), Shimadzu A.7000.

\section{Cara Kerja}

\section{Lokasi Pengambilan Sampel}

Sampel tanah diambil pada 4 lahan yaitu 2 lahan pertanian organik dan 2 lahan pertanian anorganik. Setiap lahan sawah diambil tanah pada tiga petak lokasi yaitu pada Hilir, Hulu dan tegah, setiap petak dibagi 5 titik sampel, Sampel tanah diambil menggunakan sendok plastik, kemudian dimasukkan ke dalam plastik kantong polietilen. Sampel diambil pada kedalaman 0-20 cm sebanyak 500 gram. tanah pada setiap titik sampling.

\section{Perlakuan Sampel Tanah}

Sampel yang telah terkumpul dibawa ke laboratorium untuk diproses lebih lanjut. Sampel tanah organik dan tanah anorganik di masukkan ke dalam oven dan dipanaskan pada suhu tidak lebih dari $60^{\circ} \mathrm{C}$, sehingga diperoleh berat konstan. Sempel tanah yang sudah kering kemudian digerus dan diayak dengan ayakan $63 \mu \mathrm{m}$. Sampel tanah yang akan dianalisis adalah sampel tanah yang berukuran $\leq 63 \mu \mathrm{m}$ (Siaka et al., 2006).

\section{Pembuatan Larutan Standar Cu dan Zn} Larutan induk $\mathrm{Cu}$ dan $\mathrm{Zn} 100 \mathrm{mg} / \mathrm{L}$ dibuat dengan menimbang sebanyak 0.249. $5 \mathrm{~g} \quad \mathrm{CuSO}_{4} .5 \mathrm{H}_{2} \mathrm{O}$, dan $0,315 \mathrm{~g}$ $\mathrm{Zn}\left(\mathrm{NO}_{3}\right)_{2} .7 \mathrm{H}_{2} \mathrm{O}$ kemudian dilarutkan dengan $\mathrm{HNO}_{3} \quad 0,01 \mathrm{M}$ dan diencerkan hingga volume $100 \mathrm{~mL}$. Larutan standar $\mathrm{Cu}$ konsentrasi $0,1,2,4 \mathrm{ppm}$ dan $\mathrm{Zn} \mathrm{0,}$ 0.25, 0.5 dan 1 ppm Masing masing larutan standar diukur dengan AAS untuk pembuatan kurva kalibrasi.

Ekstraksi Tahapan 1 (Fraksi Easly, Freely, Leachable, and Exchangeable).

$1 \mathrm{~g}$ tanah dimasukkan ke dalam tabung ekstraksi, ditambahkan $40 \mathrm{~mL} \mathrm{CH}_{3} \mathrm{COOH} 0,1$ M. Campuran di gojog selama 2 jam, disentrifugasi dengan kecepatan $4000 \mathrm{rpm} 10$ menit, Lapisan cairan yang terbentuk didekantasi ke dalam labu ukur $50 \mathrm{~mL}$, diencerkan dengan $\mathrm{HNO}_{3} 0.01 \mathrm{M}$ sampai tanda batas. Sempel dianalisis dengan AAS. Residu digunakan untuk ekstraksi tahap II. 


\section{Ekstraksi Tahapan II (Fraksi Mn dan Fe Oksida).}

Residu pada ekstraksi tahap I ditambahkan $40 \mathrm{~mL} \quad \mathrm{NH}_{2} \mathrm{OH} . \mathrm{HCl} \quad 0,1 \quad \mathrm{M}$ campuran di asamkan hingga $\mathrm{pH} 2$ dengan asam nitrat. Campuran digojog selama 2 jam, disentrifugasi pada kecepatan $4000 \mathrm{rpm} 10$ menit. Cairannya di dekantasi dan diencerkan dalam labu ukur $50 \mathrm{~mL}$ menggunakan $\mathrm{HNO}_{3}$ $0.01 \mathrm{M}$ sampai tanda batas. Sampel dianalisis dengan AAS.

\section{Ekstraksi Tahapan III (Fraksi Organik dan Sulfida).}

Residu fraksi II ditambahkan $10 \mathrm{~mL} \mathrm{H}_{2} \mathrm{O}_{2}$ 8,8 $\mathrm{M}$ dan ditutup dengan kaca arloji, campuran sampel didiamkan pada suhu ruangan selama 1 jam sambil sekali-sekali dikocok. Campuran dipanaskan pada suhu $85^{\circ} \mathrm{C}$ selama 1 jam dalam penangas air. Perlakuan di ulang kembali dengan penambahan hydrogen peroksida dengan pemanasannya. Campuran didinginkan, ditambahkan dengan $20 \mathrm{~mL} \mathrm{CH}_{3} \mathrm{COONH}_{4} \mathrm{M}$, campuran di asamkan dg asam nitrat hingga $\mathrm{pH} 2$, campuran di gojok 2 jam dan di sentrifugasi dengan kecepatan $4000 \mathrm{rpm} 10$ menit. Cairannya didekantasi ke dalam labu ukur $50 \mathrm{~mL}$, dan di encerkan dengan akuades hingga tanda batas. Larutan dianalisis menggunakan AAS.

\section{Ekstraksi Tahapan IV (Fraksi Resistant)}

Residu tahap III ditambahkan $10 \mathrm{~mL}$ reverse aquaregia (campuran $\mathrm{HNO}_{3}$ dan $\mathrm{HCl}$ (3:1)). Campuran didigesti dengan ultrasonic bath selama 45 menit pada suhu $60^{\circ} \mathrm{C}$. campuran dipanaskan pada hotplate selama 45 menit pada suhu $140^{\circ} \mathrm{C}$. Hasil digesti ditambah akuades sekitar $30 \mathrm{~mL}$ dan disaring. Filtrat dimasukkan ke dalam labu ukur $50 \mathrm{~mL}$ dan ditambah akuades hingga tanda batas. Semua larutan dari hasil ekstraksi diukur konsentrasi logam $\mathrm{Cu}$ dan $\mathrm{Zn}$ nya menggunakan AAS pada panjang gelombang $324,7 \mathrm{~nm} \mathrm{Cu}$ dan 213,9 nm untuk logam $\mathrm{Zn}$. Penentuan konsentrasi dilakukan dengan menggunakan metode kurva kalibrasi standar (Siaka et al., 2006). Selanjutnya kandungan tiap fraksi dihitung menggunakan rumus:

$$
\mathrm{M}=\frac{C X V X f}{B}
$$

Logam total dari $\mathrm{Cu}$ dan $\mathrm{Zn}$ dihitung dengan cara menjumlahkan kandungan setiap fraksinya ( fraksi 1-4).

\section{HASIL DAN PEMBAHASAN}

\section{Kurva Kalibrasi Larutan Standar}

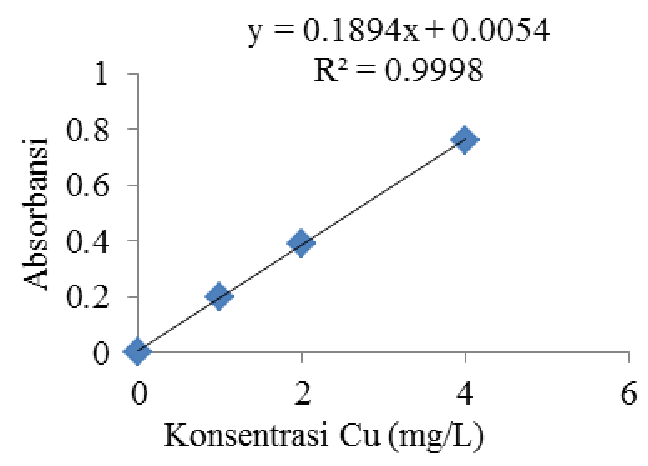

Gambar 1. Kurva kalibrasi standar $\operatorname{logam} \mathrm{Cu}$

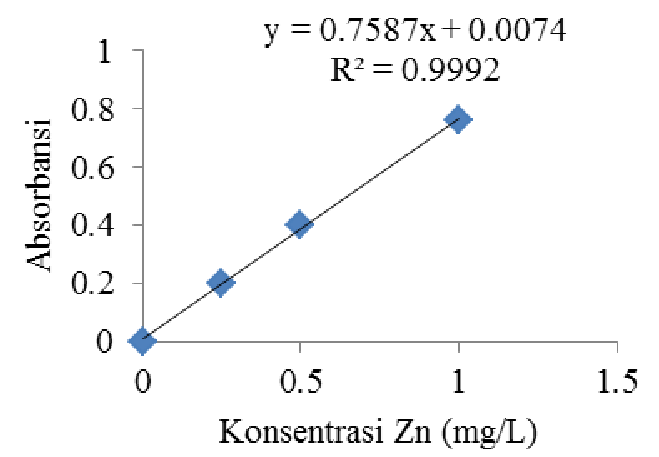

Gambar 2. Kurva kalibrasi standar logam Zn

Persamaan regresi linier untuk logam $\mathrm{Cu}$ yaitu $\mathrm{y}=0.1894 \mathrm{x}+0.0054$ dengan nilai regresi $\left(R^{2}\right)=0,9998$ dan persamaan regresi linier logam $\mathrm{Zn}$ yaitu $\mathrm{y}=0.7587 \mathrm{x}+0.0074$ dengan nilai regresi $\left(R^{2}\right)=0,9992$. Kurva kalibrasi logam $\mathrm{Cu}$ dan $\mathrm{Zn}$ ditunjukkan oleh Gambar 4.1 dan 4.2

Nilai regresi kurva kalibrasi yang diperoleh menunjukkan linearitas yang cukup, karena memiliki nilai $>0,9970$, sehingga absorbansi logam setiap sampel dapat dihitung berdasarkan persamaan regresi liniernya. Nilai regresi ini sesuai pendapat Chan et al.,(2004) bahwa linieritas kurva kalibrasi yang baik dan valid memiliki nilai regresi $\left(\mathrm{R}^{2}\right)$ minimal 0,9970 . Hasil dari persamaan regresi linier pada Gambar 4.1 dan 4.2 digunakan untuk menghitung konsentrasi logam $\mathrm{Cu}$ dan $\mathrm{Zn}$ pada masing-masing fraksi. Dengan menghitung konsentrasi setiap fraksi dan menjumlahkannya maka didapatkan konsentrasi $\mathrm{Cu}$ dan $\mathrm{Zn}$ total pada tanah organik dan anorganik. 


\section{Kandungan $\mathrm{Cu}$ total Tanah Organik dan Anorganik}

Kandungan rata-rata logam $\mathrm{Cu}$ dalam tanah Organik dan anorganik berkisar 35,1754$46,9754 \mathrm{mg} / \mathrm{kg}$ dan 44,5033-52,4543 mg/kg Kisaran ini masih berada dalam kategori tidak tercemar, seperti tanah yang sudah dinyatakan tercemar oleh GLC (the former greater London council) bahwa katagori tidak tercemar untuk logam $\mathrm{Cu}$ berkisaran $0-100 \quad \mathrm{mg} / \mathrm{kg}$ (Alloway,1990). Ini berarti bahwa tanah pertanian organik tersebut belum dikatakan tercemar baik oleh $\mathrm{Cu}$. Secara umum kandungan $\mathrm{Cu}$ total dalam tanah anorganik lebih tinggi dibandingkan dengan tanah organik, seperti grafik yang disajikan pada Gambar 3.

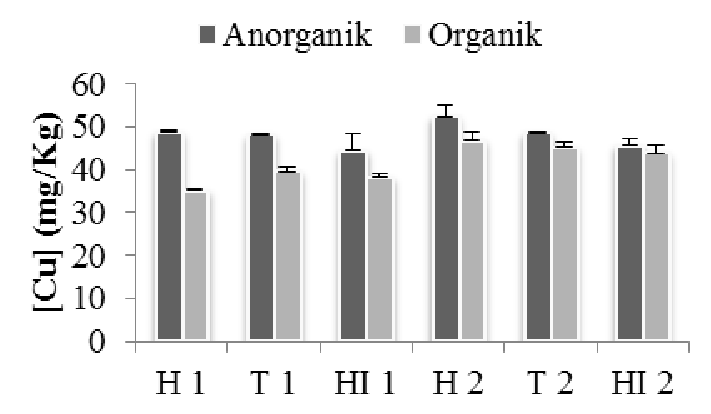

Keterangan : $\mathrm{H}=\mathrm{Hulu}$; T= Tengah; $\mathrm{HI}=$ Hilir

Gambar 3. Perbedaan kandungan logam $\mathrm{Cu}$ total pada tanah pertanian organik dan anorganik

Menurut Jones et al (1991) tidak semua unsur hara dapat diserap tanaman karena tanaman umumnya menyerap lebih dari 50 unsur, berarti sekitar $70 \%$ unsur- unsur ini bukan hara tanaman. Berdasarkan bobot kering $(\mathrm{mg} / \mathrm{kg})$ kebutuhan unsur hara tanaman terhadap logam-logam $\mathrm{Cu}<\mathrm{Zn}$ yang berkisaran $6-20 \mathrm{mg} / \mathrm{kg}$.

Kandungan logam $\mathrm{Cu}$ pada tanah organik yang diperoleh pada penelitian ini sudah memenuhi persyartan, dimana kebutuhan unsur hara tanaman dalam bobot kering maksimal 20 $\mathrm{mg} / \mathrm{kg}$ (Jonnes et al., 1991). Walaupun unsur hara $\mathrm{Cu}$ dan $\mathrm{Zn}$ yang diperoleh lebih tinggi dari batasan maksimal yang ditentukan, namun tidak semua logam $\mathrm{Cu}$ dan $\mathrm{Zn}$ total tersebut bioavailable. Kekurangan $\mathrm{Cu}$ pada tanaman akan mengakibatkan daun tanaman layu. Defisiensi $\mathrm{Cu}$ tanaman terjadi lebih sering pada tanah organik dan tanah berpasir dengan intensitas pelinding yang tinggi karena logam $\mathrm{Cu}$ cenderung terikat pada bahan organik. Hal ini juga dapat terjadi pada logam $\mathrm{Zn}$, namun afinitas $\mathrm{Zn}$ terhadap organik lebih keci dari pada $\mathrm{Cu}$.

\section{Kandungan Zn Total dalam Tanah Organik dan Anorganik}

Konsentrasi rata-rata logam $\mathrm{Zn}$ dalam tanah organik anorganik 1 dan 2 berkisaran 40,2590-49,8446 mg/kg dan 43,5953-54,1797 $\mathrm{mg} / \mathrm{kg}$. Kandungan logam $\mathrm{Cu}$ dan $\mathrm{Zn}$ total pada tanah anorganik berada dalam kisaran logam yang belum tercemar, sesuai dengan persyaratan GCL (the former greater London council) untuk logam $\mathrm{Zn}$ yang belum mengalami pencemaran berkisaran 0-250 $\mathrm{mg} / \mathrm{kg}$ (Alloway,1990). Kandungan logam yang diperoleh dari tanah anorganik lebih tinggi dibandingkan pada tanah pertanian organik yang di klaim sudah berlangsung selama 2 tahun. Perbedaan kandungan Zn total dalam ke dua jenis tanah pertanian tersebut dapat dilihat pada Gambar 4.

Kisaran kandungan logam yang diperlukan oleh tanaman dalam penyerapan unsur hara untuk logam $\mathrm{Cu}$ dan $\mathrm{Zn}$ adalah 6-20 $\mathrm{mg} / \mathrm{kg}$, dan pada tanah anorganik kandungan logamnya sudah melebihi ambang batas kebutuhan tanaman, sehingga tidak akan terjadinya defisiensi logam Zn pada tanah anorganik.

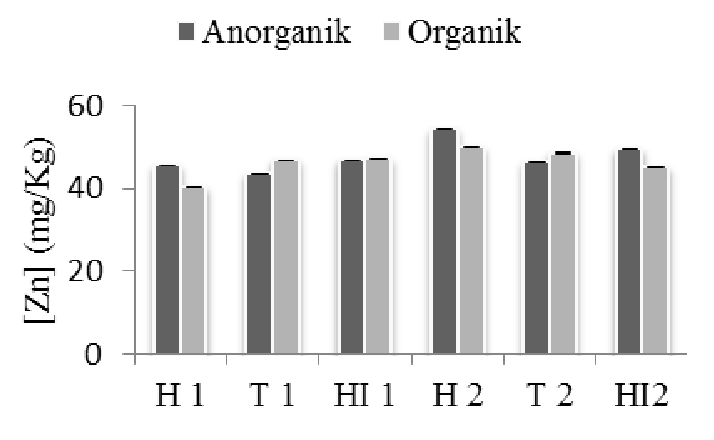

Keterangan $: \mathrm{H}=\mathrm{Hulu} ; \mathrm{T}=$ Tengah; $\mathrm{HI}=$ Hilir

Gambar 4. Perbedaan kandungan logam zn total pada tanah pertanian organik dan anorganik

\section{Bioavailabilitas Logam $\mathrm{Cu}$ dan $\mathrm{Zn}$ dalam Tanah Organik dan Anorganik}

Spesiasi dan Bioavailabilitas logam berat $\mathrm{Cu}$ dan $\mathrm{Zn}$ dapat ditentukan melalui proses ekstraksi bertahap. Berdasarkan spesies logam $\mathrm{Cu}$ dan $\mathrm{Zn}$ dapat ditentukan logam-logam yang 
bioavailable, berpotensi bioavailable, dan non bioavailable. Hasil dari tahapan tahapan tersebut berupa konsentrasi masing-masing fraksi, Konsentrasi masing-masing fraksi tersebut dijumlahkan untuk menghitung konsentrasi total, dan selanjutnya dapat digunakan untuk menentukan persentase logam terekstraksi pada setiap fraksi.

$$
\square \mathrm{Cu}(\%) \quad \mathrm{Zn}(\%)
$$

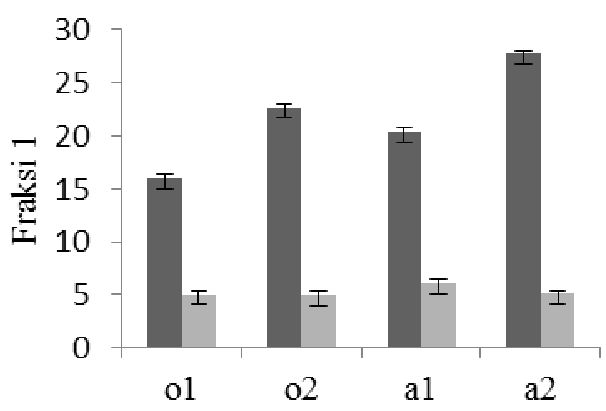

Keterangan : $\mathrm{o}=$ organic; $\mathrm{a}=$ anorganik.

\section{Gambar 5. Persentase $\mathrm{Cu}$ dan $\mathrm{Zn}$ pada fraksi} 1 (EFLE)

Tahapan pertama ekstraksi bertahap menggunakan larutan asam asetat untuk mengekstraksi logam-logam yang mudah terionisasi, terkikis, mudah tertukarkan, dan yang berikatan dengan karbonat tanpa merusak spesies yang lain. fraksi 1 juga merupakan fraksi yang sangat labil sehingga logam pada fraksi ini akan bersifat bioavailable atau bersifat toksik. Pada fraksi 1 senyawa logam yang larut dengan air dan asam lemah, akan membentuk ion, dan yang cenderung berupa senyawa karbonat maupun ionik (Gasparatos et al., 2005). Tanah pertanian organik dengan $\%$ ekstraksi pada tahap 1 untuk logam $\mathrm{Cu}$ berkisar 10,52-23,79\% dan tanah pertanian anorganik berkisar 18,31-32,63\%. Persentase logam Zn dalam tanah organik dan anorganik yang terekstraksi pada tahap ini berturut-turut pada sasaran 3,66-7,21\% dan 4,54-7.58\% dan persentse fraksi ini terendah dibanding fraksifraksi lainnya. Ini berarti bahwa logam $\mathrm{Zn}$ yang bioavailabel dari kedua jenis tanah tersebut tidak lebih dari 6\% dari logam totalnya. Akan tetapi \% $\mathrm{Cu}$ yang bioavailable lebih tinggi dari pada Zn yaitu sekitar 3-4 kali $\mathrm{Zn}$ seperti gambar yang ditunjukkan pada Gambar 5.
Dengan demikian, dapat dikatakan bahwa Zn yang tersedia atau bioavalabel berada pada kisaran yang dibolehkan (6-20 $\mathrm{mg} / \mathrm{kg})$, sedangkan $\mathrm{Cu}$ dalam tanah anorganik di atas batas maksimum yang diperbolehkan (Jonnes et al., 1991). Ini mengindikasikan bahwa baik $\mathrm{Cu}$ maupun $\mathrm{Zn}$ kemungkinan besar tidak menyebabkan tanaman yang tumbuh pada tanah organik mengalami kelebihan kontaminasi $\mathrm{Cu}$ dan $\mathrm{Zn}$, kecuali pada tanah anorganik yang $\mathrm{Cu}$ bioavailabelnya di atas 20 $\mathrm{mg} / \mathrm{kg}$

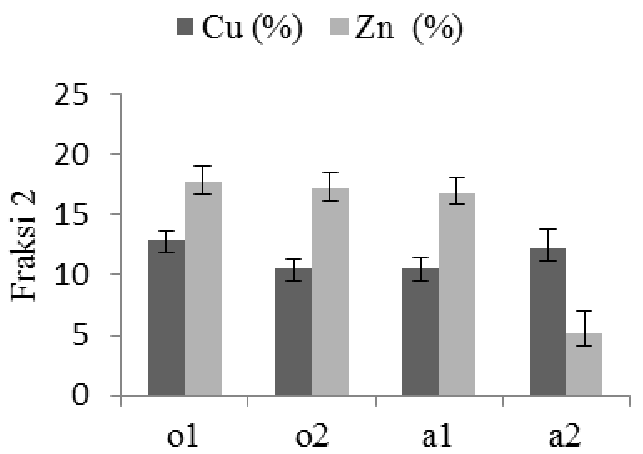

Keterangan : o = organic; $\mathrm{a}=$ anorganik.

Gambar 6. Persentase $\mathrm{Cu}$ dan $\mathrm{Zn}$ pada fraksi 2 (reducible)

Fraksi 2 diperoleh dari ekstrak menggunakan Hydroxylamine hidro klorida yang berfungsi untuk mengekstrak logamlogam secara potensial dapat direduksi oleh reduktor kuat yang terikat pada lapisan oksida $\mathrm{Mn} / \mathrm{Fe}$. Logam - logam yang terikat dengan $\mathrm{Mn} / \mathrm{Fe}$ oksida atau hidroksida akan mudah lepas ketika direduksi dengan asam pada keadaan tertentu (Tersier et al, 1979). Logam yang terekstrak dari tahapan ini dapat berpotensi bioavailable. Logam-logam yang terikat pada fraksi 2 cendrung lebih kuat dan stabil dari fraksi 1, stabilitas ikatan ini akan lepas jika keadaan potensial redox (Eh) dalam tanah rendah sehingga logamnya dapat lepas membentuk ion. (Gasparatos et al, 2005). Berbeda dengan fraksi 1 , persentase $\mathrm{Cu}$ yang terikat pada $\mathrm{Fe} / \mathrm{Mn}$ oksida pada kedua jenis tanah lebih rendah dibandingkan dengan $\mathrm{Zn}$. Spesies $\mathrm{Cu}$ yang bersifat reducible ini tidak lebih dari $13 \%$ dalam ke dua jenis tanah tersebut, sedangkan $\mathrm{Zn}$ sekitar $18 \%$ berada dalam fraksi reducible (Gambar 6) 


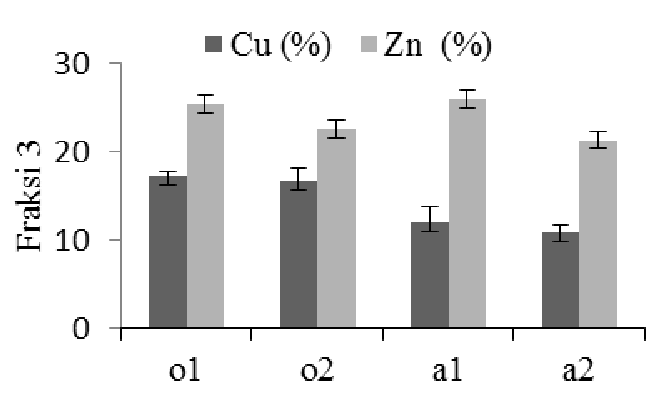

Keterangan $: \mathrm{o}=$ organic; $\mathrm{a}=$ anorganik

Gambar 7. Persentase Cu dan Zn pada fraksi 3 (oxidisable)

Fraksi 3 diperoleh dengan mengekstraksi tanah dengan oksidator kuat hydrogen peroksida untuk melepaskan ikatan-ikatan logam berat yang berasosiasi atau terikat pada senyawa organik dan sulfida. Rata-rata persentase terekstraksi logam berat $\mathrm{Cu}$ pada tanah organik lebih tinggi dibandingkan pada anorganik seperti terlihat pada Gambar 4.7. Ini membuktikan bahwa tanah pertanian yang diklaim sebagai tanah organik cukup masuk akal karena $\mathrm{Cu}$ lebih bnyak terikat pada tanah yang mengandung bahan organik, sebab $\mathrm{Cu}$ mempunyai afinitas lebih besar terhadap bahan organik. Berbeda dengan $\mathrm{Zn}$, terlihat bahwa baik pada tanah organik maupun anorganik $\mathrm{Zn}$ terikat hampir sama. Fraksi 3 dikatakan sebagai fraksi oxidizable, namun logam-logam yang terikat pada fraksi 3 cenderung lebih stabil dari fraksi 2 dan ikatan ini dapat terdegradasi oleh keberadaan oksidator kuat di lingkungan logam-logam $\mathrm{Cu}$ dan $\mathrm{Zn}$ pada fase ini merupakan logam yang berpotensi bioavailabel persentase $\mathrm{Cu}$ yang terekstraksi dari tanah organik lebih besar pada tanah anorganik,, maka dapat dikatakan bahwa tanah pertanian organik yang sudah berlangsung selama 2 tahun dapat memiliki kandungan organik yang lebih besar. Keberadaan organik yang lebih besar, Keberadaan organik yang cukup tinggi pada tanah dapat disebabkan oleh penggunaan pupuk organik, namun pada kenyataannya, kandungan C-organik pada tanah organik justru lebih rendah disbanding C-organik pada tanah anorganik.

Siaka (2016) melaporkan bahwa konsentrasi logam $\mathrm{Cu}$ tertinggi sekitar $40 \%$ $(32.42-46,73 \%)$ terikat pada fraksi 3. Fasa organik dan sulfida, dapat mengikat dan menyerap $\mathrm{Cu}$ dalam tanah lebih banyak karena afinitas $\mathrm{Cu}$ sangat kuat terhadap organik (Reichman,2002). Rata- rata persentase logam
Zn yang terekstraksi dari tanah organik dan anorganik berada pada kisaran 22,58-25,36\% dan 21,33-25,90\% (Gambar 7). Logam Zn yang berasosiasi dengan fasa organik baik pada tanah pertanian organik maupun anorganik terlihat sama sehingga keberadaan spesies organik/sulfida lebih besar. Hal ini dapat dikatakan bahwa yang di klaim sebagai tanah organik ternyata masih dipengaruhi oleh residu pupuk anorganik, karena tanah ini baru 2 tahun mengalami peralihan. Tanah organik memiliki sifat yang sepenuhnya organik minimal selama 6 tahun (Diara, 2015).

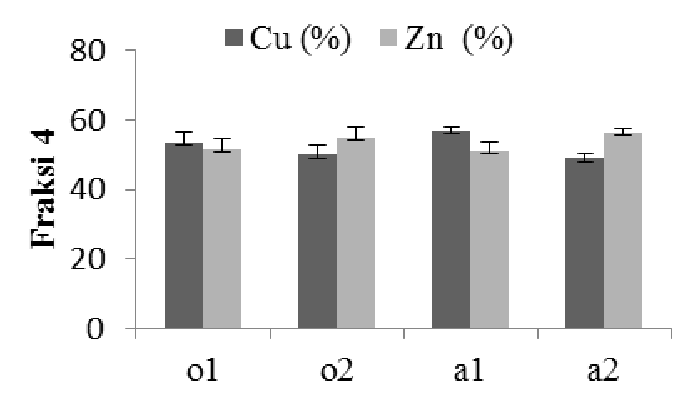

Keterangan $: o=$ organic; $a=$ anorganik

Gambar 8. Persentase $\mathrm{Cu}$ dan $\mathrm{Zn}$ pada fraksi 4 (resistant)

Fraksi 4 ( Fraksi Resistant) merupakan fraksi yang paling stabil dan paling sulit diekstraksi dalam tanah. Logam-logam yang ada pada fraksi ini merupakan logam yang terikat pada mineral-mineral primer dan silikat. Logam-logam pada fraksi ini dapat diekstraksi melalui proses digesti dengan reverse aquaregia pada ultrasonic bath dan hot plate. Dengan demikian, logam-logam yang berasosiasi pada fraksi ini merupakan fase inert dan tidak mungkin menjadi ion, sehingga logam tersebut bersifat non bioavailable. Spesies logam $\mathrm{Cu}$ dan $\mathrm{Zn}$ pada fasa ini bukan berasal dari pencemaran dari aktivitas manusia. Spesies pada fase 4 ini merupkan fraksi yang paling tinggi diantara fraksi-fraksi yang lainnya. Rata-rata persen ekstraksi $\mathrm{Cu}$ dan $\mathrm{Zn}$ pada kedua jenis tanah ini terlihat hampir sama seperti yang disajikan pada gambar 8

Persen ekstraksi logam $\mathrm{Cu}$ tanah organik dan anorganik berkisaran 50,02-53,77\% dan $49,12-57,01 \%$ dan logam $\mathrm{Zn}$ yaitu 51,83$55,20 \%$ dan $51,23-56,66 \%$. berdasarkan hasil tersebut ini berarti, tidak kurang 55\% dari logam total baik $\mathrm{Cu}$ maupun $\mathrm{Zn}$ terikat kuat dalam mineral kuat atau sebagai silikat. Dengan demikian, dapat dikatakan bahwa logam-logam ini berasal dari alam seperti 
pelapukan bebatuan sehingga tidak perlu di khawatirkan terjadinya kontaminasi hasil pertanian karena bersifat non bioavailable (tidak tersedia oleh hayati), dan sumber pencemaran pada fraksi ini berasal dari alam (Yap et al, 2003).

Secara umum pola penyebaran spesiasi logam pada tanah Organik adalah F4 $>$ F3 $>$ F2 $>\mathrm{F} 1$ untuk $\operatorname{logam} \mathrm{Cu}, \mathrm{F} 4>\mathrm{F} 3>\mathrm{F} 1>\mathrm{F} 2$ untuk $\mathrm{Zn}$ dan lahan pertanian Anorganik F4 $>$ F3 $>$ $\mathrm{F} 2>\mathrm{F} 1$ untuk $\operatorname{logam} \mathrm{Cu}, \mathrm{F} 4>\mathrm{F} 3>\mathrm{F} 1>\mathrm{F} 2$ untuk Zn. Berdasarkan hasil tersebut dapat dilihat bahwa logam terikat lebih banyak pada fraksi sisa atau resistan dan yang paling sedikit terikat padal fraksi 1 EFLE.

Bioavailabilitas logam berat $\mathrm{Cu}$ dan $\mathrm{Zn}$ dapat dilihat dari spesies-spesies logam tersebut yang berasosiasi pada fase masingmasing fraksinya. Logam yang bioavailable adalah spesies yang berada pada fraksi 1 (EFLE), logam yang berpotensi bioavailable adalah spesies-spesies yang berasosiasi pada fraksi Fe/Mn oksida dan fraksi organik/sulfida, dan logam yang tidak bioavailable adalah spesies-spesies logam yang terdapat pada fraksi resistant $(\mathrm{F} 4)$.

\section{SIMPULAN DAN SARAN}

\section{Simpulan}

Berdasarkan hasil penelitian yang telah dilakukan maka dapat disimpulkan sebagai berikut:

Konsetrasi rata-rata logam berat $\mathrm{Cu}$ dan $\mathrm{Zn}$ total pada tanah pertanian yang diperoleh berturut-turut 37,6990-45,3922 $\mathrm{mg} / \mathrm{kg}$ dan $44,7237-47,7648 \mathrm{mg} / \mathrm{kg}$ pada tanah organik dan 47,1440-48,9121 mg/kg dan 45,2733$49,9474 \mathrm{mg} / \mathrm{kg}$ pada tanah anorganik. Kedua jenis tanah pertanian tersebut dikatagorikan belum tercemar.

Spesiasi $\mathrm{Cu}$ dan $\mathrm{Zn}$ dalam tanah baik tanah organic maupun anorganik didominasi oleh spesies resistant dan terkecil adalah spesies EFLE untuk logam $\mathrm{Cu}$ dan reducible untuk $\mathrm{Zn}$ dengan urutan sebagai berikut $\mathrm{F} 4>\mathrm{F} 3>\mathrm{F} 2>\mathrm{F} 1$ untuk $\mathrm{Cu}$ dan $\mathrm{F} 4>\mathrm{F} 3>\mathrm{F} 1>\mathrm{F} 2$ untuk Zn.

Logam $\mathrm{Cu}$ dan $\mathrm{Zn}$ yang bioavailable, berpotensi bioavailable dan non bioavailabel berturut-turut $16,04-22,67 \%$ dan $5,02-5,05 \%$; $10,55-17,22 \%$ dan $17,20-25,36 \%$; 50,02$53,77 \%$ dan $51,83-55,20 \%$ pada tanah organik dan 20,43-27,73\% dan 5,11-6,04\%; 10,53-
$12,21 \%$ dan $16,84-25,90 \%$; 49,12-57,01\% dan $51,23-56,66 \%$ pada tanah anorganik.

\section{Saran}

Perlu dilakukan penelitian lebih lanjut mengenai spesiasi dan bioavailabilitas logam $\mathrm{Cu}$ dan $\mathrm{Zn}$ dan logam berat lainnya pada tanah pertanian organik yang sudah bersertifikasi organik untuk menentukan penurunan tingkat bioavailability logam berat tersebut terhadap lama waktu penggunaan sebagai tanah pertanian organik.

\section{UCAPAN TERMAKASIH}

Penulis mengucapkan terimakasih kepada orang tua dan pihak yang telah membantu dalam pembuatan karya ilmiah ini, baik pada saat penulisan dan publikasi jurnal.

\section{DAFTAR PUSTAKA}

Alloway, B. J. 1990. Heavy Metal in Soil. New York: John Willey and Sons Inc .

Alloway, B. J. and Ayres, D. J. 1997. Chemical Principles of Environmental Pollution 2nd ed, UK: Blackie Academic \& Professional. 5-46.

Diara, I. W. 2015. Sekuestraksi Karbon Organik, Kualitas Tanah dan hasil Padi (Oryza sativa L.) pada Sistem Pertanian Organik dan Konvensional. Disertasi, Pascasarjana Universitas udayana, Denpasar Bali.

Depkes. 2009. Pengenalan dan Penatalaksanaan Keracunan Pestisida. Departemen Kesehatan RI. Jakarta.

Gasparatos, D., Haidouti, C., Ardinopoulos, F., and Areta, O. 2005. Chemical Speciation and Bioavailability of $\mathrm{Cu}$, $\mathrm{Zn}$ and $\mathrm{Pb}$ in Soils from The National Garden of Athens, Greece. Proceedings of the $9^{\text {Th }}$ International Conference on Enfiromental Sciece and Technology, Rhodes Island. Geece, 1-3 September, A-438-A-444.

Jones, J. B, Wolf, B, Mills, H. 1991. Plant analysis Hand Book. United State of Amarika: Micromakro Publishing, Inc.

Priyono, J. 2006. Kimia Tanah, Mataram: Mataram University Press.

Rosmarkam, A. dan N. W. Yuwono. 2002, Ilmu Kesuburan Tanah, Yogyakarta: Kanisius. 
Siaka, M., C. M. Owens, G. F. Birch. 2006. Evaluation of some digestion methods for the determination of heavy metals in sediment samples by flame-AAS. Analyitcal letters. 31(4) : 703-718.

Siaka, M. 2016. Spesiasi dan Bioavailabilitas Logam Berat dalam Tanah dan Akumulasinya dalam Sayuran Sebagai dasar Penentuan Tingkat Aman Konsumsi. Disertasi. Pascasarjana Universitas Udayana, Falkutas Pertanian. Denpasar Bali.

Steinfeld, H., Gerbe, P., Wassena, T., Castel, V., Rosales V., de Haan, C. 2006. Livestock's Long Shadow: Environmental Issues and Options, FAO. Pp.90-91.

Steven, R. T., Somasco, O. A., Mary, K., Friedman, D. 1994. Conventional Low-Input and Organic Farming Systems Compared. California agriculture, 48(5):14-19.
Tersier, A., Campbell, P. G. C. and Bisson, M. 1979. Sequential Extraction Procedure for the Speciation of Particulate Trace Metals. Analitical Chemistry, 51 (7): 844-851.

Yap, C. K., Ismail, A., dan Tan, S. G. 2003. Concentration, Distribution and Geochemical Speciation of Copper in Surface Sedimen of the Strait of Malacca. Pakistan Journal of Biological Science, 6(12): 1021-1026.

Widaningrum, M., dan Suismono. 2007. Bahaya Kontaminasi Logam Berat Dalam Sayuran Dan Alternatif Pencegahan Cemarannya, Balai Besar Penelitian dan Pengembangan Pascapanen Pertanian. Buletin Teknologi Pascapanen Pertanian, (3): 1-12.

Widowati, W. 2008. Efek Toksik Logam. Yogyakarta: Penerbit Andi. 